\title{
BIOLLIUM による影補槡について
}

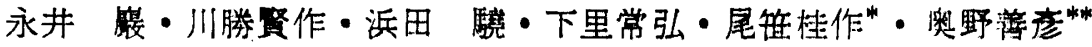

\section{I. 檤}

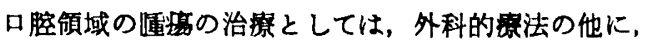
Azan, Nitromin, Sarcomycin 等の乘物燎法や，X楾， Radium, Isotope(例えばCo $0^{80}$ ) 等の放射線暴法が行われ ているが、現今の段階では未だ出来得る限り外科的根治 手術を施行し，上記の療法を垪用しなければならない场

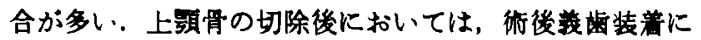
より，かなり外貎および咬合の恢復を計ることが出来る

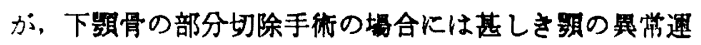
動を伴うことは当然で，為に手術時切除部位に直ちに何 物かを指入し，解剖学的ならびに機能的整復を試及る事 が必要である事は論を待たない。この意味において現在 用いられている掩入物（䅡副木）としては

\section{A. 非生体括入物}
i）金属挿入物
1) Wipla
副木
2) Vitallium
副木
3) Tantalum
副木
ii) Resin
Resin 副木

\section{B. 生体拆入物}
i）軟骨片
1）自家軟骨
2）他家軟骨
3）保存軟骨
ii) 骨 片
1）自家骨 a) 生 骨
b) 保存骨
2) 他家骨
a) 生 骨
b) 保存骨

等が応用されている.我々の教室においても従来より数 多くの下顎骨切除手術が行われておりその内, 生骨一次 移植は 25 例であって常に優秀な成縜をあげ得た．これ 等を分類すると，

1. 病理組稆学的分類 㻕瑯上皮脭

12 例

$$
\text { 癌 } 9 \text { 蕾 } 9 \text { 例 }
$$$$
\text { 肉腫 }
$$

2 例

骨婳

1 例

Cementoblastom

1. 関節頭切除

1 例

関節頭切除せざるすの

6 例

19 例

3. 移植骨の分類

\section{䁵骨}

腸骨

4. 切除骨の長さによる分類

$$
\begin{aligned}
& 5 \sim 7 \mathrm{~cm} \quad 6 \text { 例 } \\
& 7 \sim 9 \mathrm{~cm} \quad 4 \text { 例 } \\
& 9 \sim 11 \mathrm{~cm} \quad 6 \text { 例 } \\
& 11 \sim 13 \mathrm{~cm} \quad 9 \text { 例 }
\end{aligned}
$$

* 大阪大学齿学部口腔外科学教室

** 大阪大学齿学部補緅学教室

\section{その他 Resin 2 例である。}

生体移相は生体反応に上る生理的綃合が行われ，生体 に何等為害作用を是しないばかりでなく可成りの陵合压 にも耐えるよ5になるか，生理的絬合を行わしめるに可 成りの時日を要し，一部腐䏩形成を生じることがあり，

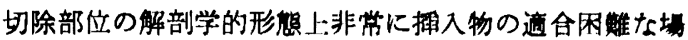
合があり，又我装湆の不可能な症例もある.

これに対し非生体移植は，取近の抗生物賀の急速な罃

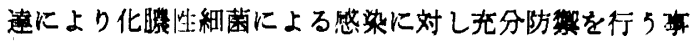
が出来るようになると共に，組維を刺㦸することなく組 樴親和性の大なる Wipla, Vitallium, Tantalum, Biollium 等が使用されるに至り, 自由な形に調使能なこ と等と合せて可成り好成筫を得，種々報告されるように なった。

今回私達は下頷骨切除を要した症例 5 例に Biollium 副木を㨉入し，その内 4 例には，口腔内に Biollium の

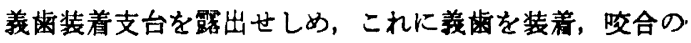
完全なる恢復を計ることが出来た. 即ち咬合力の回復と い5点から今迄の症例を卓越するものであると考えら れる。

\section{Biollium の成分および物理学的性状} 成 分

$\mathrm{Cr} \quad \mathrm{Co} \quad \mathrm{Ni}$ Mo $\mathrm{Mn} \quad \mathrm{Si} \quad \mathrm{C}$

$\begin{array}{lllllll}\text { (\%) } 28.0 & 62.0 & 5.0 & 5.0 & 0.1 & 0.3 & 0.2\end{array}$

物理学的性状

抗張力 降伏点 弾性率 伸び 比重 硬度 溶蛊点

\begin{tabular}{|c|c|c|c|c|c|c|c|}
\hline 佂 & 氏 名 & 年性 & 㐱 & 断 & $\begin{array}{l}\text { 関節 } \\
\text { 吻除 }\end{array}$ & 手術部位 & 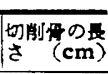 \\
\hline 1 & & 1 & 琅 & 畽 & - & 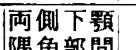 & 15.0 \\
\hline 2 & & & 珐 理 & 皮 腫 & - & $\begin{array}{c}4-3 \\
6-1\end{array}$ & 6.5 \\
\hline 3 & & 429 & 基 店 & 胞癌 & - & $4-6$ & 7.0 \\
\hline 1 & & 52 के & 唾夜 & 腫痬 & - & $8--7$ & 10.0 \\
\hline 5 & & $16 \%$ & 歯性 & 線維腫 & + & 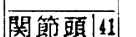 & 7.0 \\
\hline
\end{tabular}
\begin{tabular}{ccccccc}
$\mathrm{kg} / \mathrm{mm}^{2}$ & $\mathrm{~kg} / \mathrm{mm}^{2}$ & $\mathrm{~kg} / \mathrm{mm}^{2}$ & $\%$ & & ヌープ & $\mathrm{C}$ \\
\hline 60.3 & 53.0 & 21000 & 6.3 & 8.3 & 250 & 1340
\end{tabular} 用いた Biollium の成分および物理学的性状は上記の如 くである.

III. 症例

第 1 例 33 3

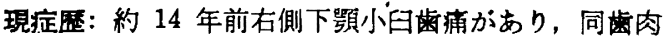
部が軽度の陣脹を来した為, 某歯科医にて切開を受け腫 脹および泈痛が消退したが，1年後同部に再度激痛を伴

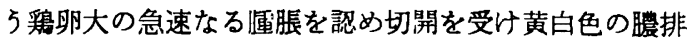
出があったとい5.その後自営㱏状なく経過したが 6 年 


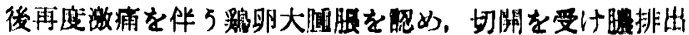

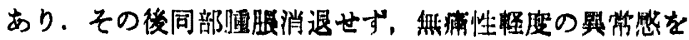
もって漸次增大して来た。

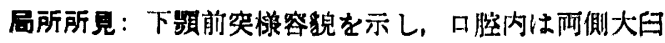

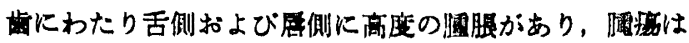

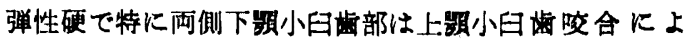

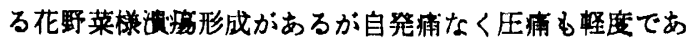

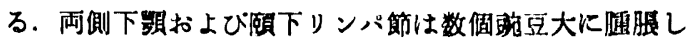
弾性硬压痛はない。

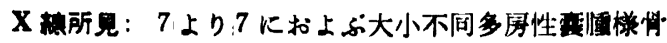

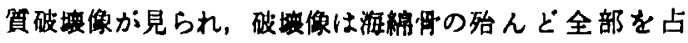

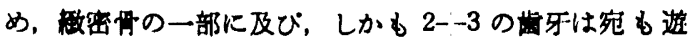
崔している如くである.

手衙及び柽遇: Morphine $0.9 \mathrm{cc}$, Atropin $0.7 \mathrm{cc}$, Thorombogen $5 \mathrm{cc} 2$ 本皮下扰よび能肉内注射し $2 \%$ Nobocain にて局所麻酔を行った. 下疑骨下绿の内方的 $2 \mathrm{~cm}$ の位置で下䫓下縟に沿い両側隅角部を結ぶ切開を

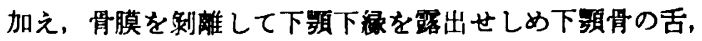

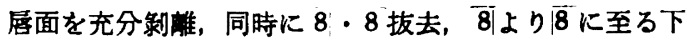
歇骨舌，层面に切開を加え骨膜を制離. $8 \cdot$ ・ 8 部にて下 㯋骨切断，窝息を避け Biollium 副木を適合，両 側下暍上行枝部にて Biollium ネヂにて固定. Biollium 副木を中心に筋肉で包被し繾合を行い，次に口腔内外に て糊膜および皮伊の縫合を行った．口腔内には両側小目 海部に 2 本の Biollium 義歯装着支台を露出せしめた. 術 後輸血 $200 \mathrm{cc}$, Linger 氏液 $500 \mathrm{cc}$, Vitacamphor 術 中, 術後 $1 \mathrm{cc}$ 各 1 本, $20 \%$ プドウ糖, $20 \mathrm{mg} \mathrm{VB}, 100$ $\mathrm{mg}$ V.C 各 1 本, Mycillin 朝夕 $0.5 \mathrm{~g}$ 宛, Penicillin 5 万単位 3 時間毎, 酸素吸入, Achromycintroches 1 日 3 錠を投与した. 術後 5 日目に口胵外拔系，9 日目に 口腔内抜系終了．30日目に義崡を装着せしめ得た，術後 6 ケ月を経過しているか，何等異常を認めない。

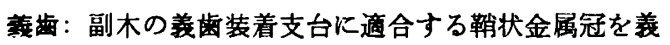
歯に固定し，義崡の維持を副木に求めた.

摘出物：前後径 $4 \sim 5 \mathrm{~cm}$ ，高さ $7 \mathrm{~cm}$ に膨大した下穎 切除物で, $6321 / 126$ が残存, 左右小四歯部に直 径 $2 \sim 3 \mathrm{~cm}$ 不正円形噴火状の漬㷎形成部があり，その 底は凹凸不正，花野菜様である。

病理組織学的跈断名 : Adamantinoma (Acanthoma type)

病理組織学的所見：腫瘍組織は間質結合織中に宩状に 增殖し, 各細胞は胎生期陆瑡器に見られるすのと類似し ているか，所々の鉴中央部において涮平上皮化の傾向を 示すもの，瘇煌組織の融解により䧶睡を形成しつつある のが認められる.これらの腫湯組織は潰場部に㧊いて肥 厚增殖せる重層屚平上皮に移行している. 尚間質の巣に 対する部分は硝子様であり, 間質中にも变腫の形成が詔 められる外, 可成りの炎症細胞浸潤がある.リンハ腺に は慢性炎のある外，転位は認められない。

\section{基 2 侧 37 \&}

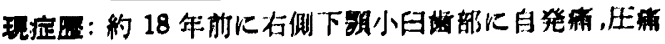

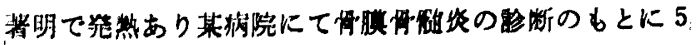

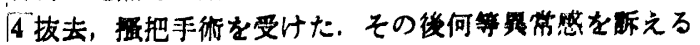

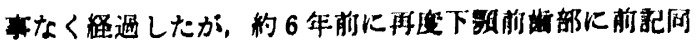

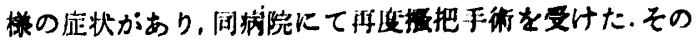

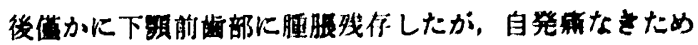
放措していたが約 6 ケ月前より自発腫を路めるに至った。

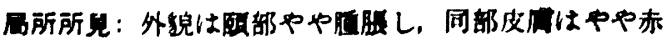

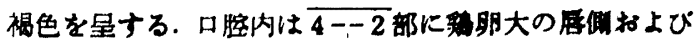

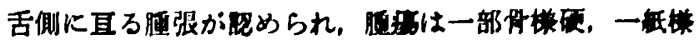

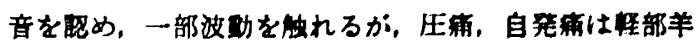
皮度である. 来籼により，約 10cc の赤花他コレステリ

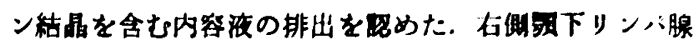

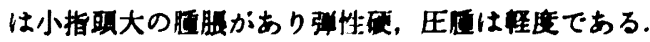

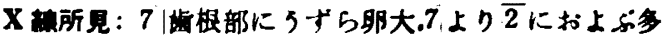

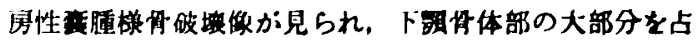

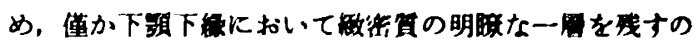
みである.

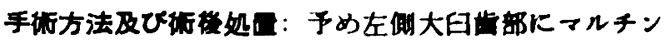

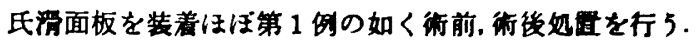

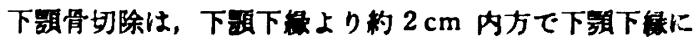

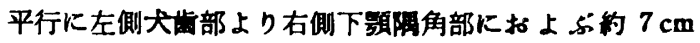

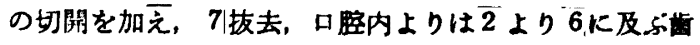
堤上に切開を加え，下颔骨を切断す。. Biollium 副木は 槽左側小目部および右側下影㶲角部にて Biollium ネ ジにて固着した. 術後 11 日目抜系完了. 術後 30 日目

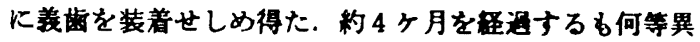
莹を贎めない.

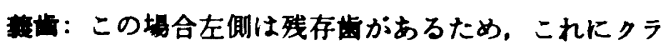
スプを応用し右側は前例と同様，義齔装着支台に遥合す る鞘状金属冠をそれぞれ義均に附着した。

摘出物：大きさ $6 \times 4 \times 5 \mathrm{~cm}$ に膨隆せる下頂骨部分切 除物で，齿牙はすぺて欠損，下暍骨骨体は腫湯の增殖に より全く破買され，2ヶの杰腫により置换されている. 内面は一般に平滑である，下歌骨は骨様硬であるが，一 部破壊吸収され波動を触れる。

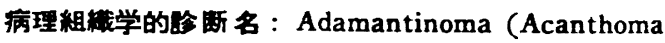
type)

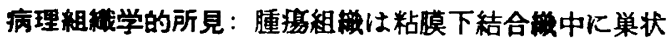
に增殖し昢瑯器に類する組樴構造を示し, 巣中央部に 角化重畦体を形成するすのが多数見受けられる. 間質中 には怪度の円形細胞浸洞が訆められる. 表腫内壁を形成 する上皮細胞層は珠瑯器のそれに類似し，基底部の細胞 は侮子型であるが上首は渐次星芒状粗となり，制離しつ つある外，壁中にコルベン状或は荣状に增殖しているの が認められる.

第 3 例

現症歴：䄪 10 年前に下影前雪部舌側に梅干大, 無痛 
性，弾性軟の腫镸に気付き某病院にて摘出手微を受けた。

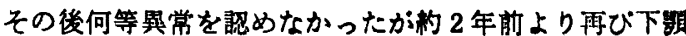

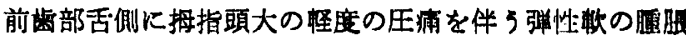
を認め，轻度の異常感を伴って增大して来たので約 9 ケ 月前に同病院にて摘出手彭を受けたが䄪 6 ケ月以前より

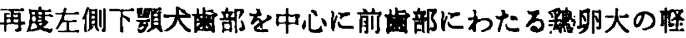

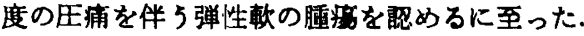

局所所見： $\overline{5}$ 上り $\overline{6}$ にわたる雨慢性腫脤があり，强性 硬圧痛軽度，波動を認めない，所属りンパ節は蜰知しない。

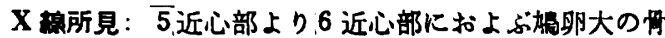
破壞像が見られ，境界はやや不明璄で悪性像を思わしめ。

下㯋下悢に骨の一㕣を残すのみである.

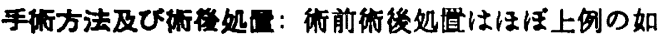

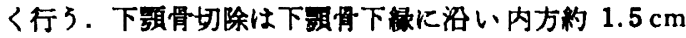
の位置で右側小臼齿部より左側大曰部に及ぶ約 $8: n$

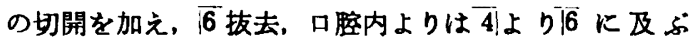
畨槽堤上に切開を加元， $\overline{5} \mid$ の近心䄪 $0.5 \mathrm{~cm}, \overline{7}$ の近心䄪 $0.5 \mathrm{~cm}$ の位置で下頴骨を切断, Biollium 副木を適合, Biollium ネシ 4 本にて固着した. 術後 9 日目に抜系完 了, 術後 35 日目に退院せしめ得た. 以後X袮療法を行 っている為義齿は未だ装着していない。

摘出物：左側下䫑杹頁部を含む下㯋骨部分切除物で，下

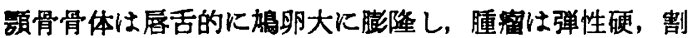

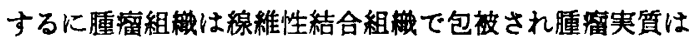

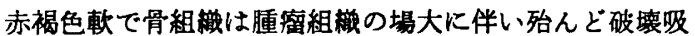
収され一部においては骨膜を残すのみである.

病理組䋞学的崄断名: Basal cell canser

病理組織学的所見：腫瘏組織は巣状に一部間質結合機 と混交しつつ旰盛に增殖し腫㻛細胞は巣周辺部ではクロ マチンに富む核を有し胞体は版子型乃至は円柱型で巣中 央部では紡锤型或は星艺状で，排列もやや粗となり核分 剖は殆んど見当らないが可成りの多型性が覗われる. 他 方間質結合組樴は巣に接し一部粘液様であるが一般には 線維性結合組織よりなり，その中に骨様組樴，骨等の形 成が誢われる外，巨細胞によって吸収されつつある所 謂fibroostitic な像が見受けられる。

第 4 例 $52 \delta$

現症歴：䄪 3 年前右側下影小四齿部に軽度の異常感を 伴つて舌側と特に煩側に腫脹を来し某外科にて班瑯上皮 腫の診断の下に提把摘出手術を受けたが，その後一年経 過して同部位に再度軽度の疼痡を伴 5 腫脹を認め再び强 把摘出手術を受けた. 約 1 年前より同部位並びに左側小 臼歯部に再び異常感を覚え某病院にて Radium, $\mathrm{Co}^{80}$ 療 法を受けた。

局所所見：外貌は下㯋骨体部軽度腫脹し右側顯下部お よび䫝下部の外皮は放射線療法の為と思われる赤褐色の

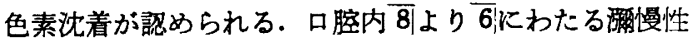
腫脹があり, 腫瘤は一部骨样硬, 一部弾性硬, 一部波動 を触れる，自発痛なく压痛は軽度で潰埸形成は認めない。

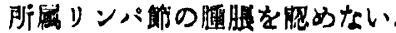

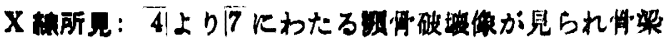

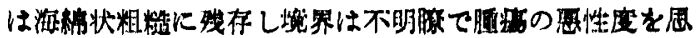

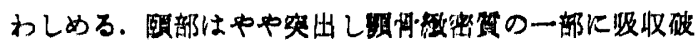

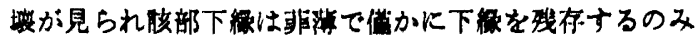
である.

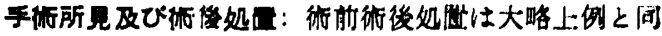

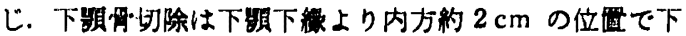

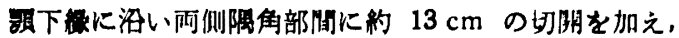

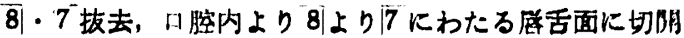

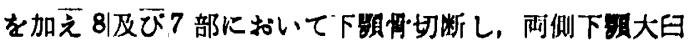
部にて Biollium ネデにて固着した。很後 10 日目に て拔系完了した。

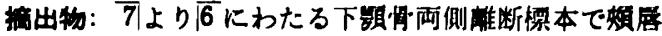

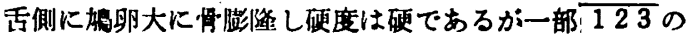
层側において波動を视む．割すると影骨骨䁈は殆んど破

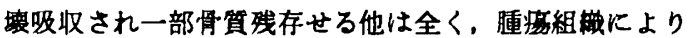
登換されている. 割面の色調は带黄灰白色粗精で所々に

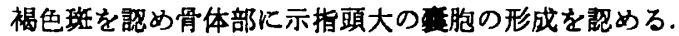

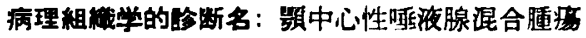

病理租悢学的所見：腫的細胞は多型性で squamous cells, oxyphilic granular cells, sebaceous cells 等 を思わしめる細胞の他に口简上皮に類する明瞭な原形質 をもった大きな細胞も見受けられ，円形或は棈円形の核 を有し，核のクロマチン基は粗大，顆粒状核分剖像む見 られる。これら細胞は間質結合機中に大小種々の柴を形 成しつつ增殖すると共に一部においては空洞を形成して いるのが瞀われる．間質は箖粗な結合機よりなり異物巨 態細胞型の巨態細胞が多数見られ一部 myxomatous で 血管の拡張，盈充が見られる．骨膜は線維状に肥厚して

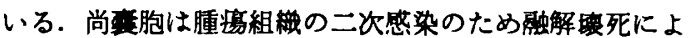
り生じた仮性敦胞と思われた。

第5例— 15 \%

現症歴：約 1 年 3 ケ月前に右側下颚隅角部に無痡性の 腫脹を認めたが疼痡なきため放䁂していたが都次增大し 拳大の腫㴏を訆めるに至った。

局所所見：外貌は右側下影隅角部扰よび頡下部に強度 の硒慢性腫脤があり骨様硬，波動は蜰れない，口腔内は 7 6部の煩側に清海形成が認められ，周囲はやや硬結を 触れ底部は花野菜様である. 圧痛, 自発痡共になく所属 リンパ節は触れない。

$\mathrm{X}$ 線所見： $\overline{4} \mid$ より関節頭に及ぶ大小不同多房性軎腫様 骨破壊像が見られる。

手衍方法及び街後処是：術前術後処置は大略上例に同 じ. 下疑骨切除は下影骨下绿の内方的 $2 \mathrm{~cm}$ の位置で下 顎下縁に沿い, 4 より耳下部にわたる約 $7 \mathrm{~cm}$ の切開を

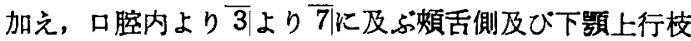

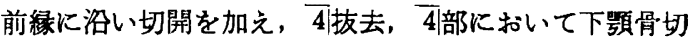

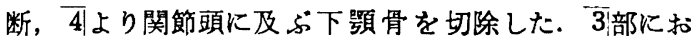



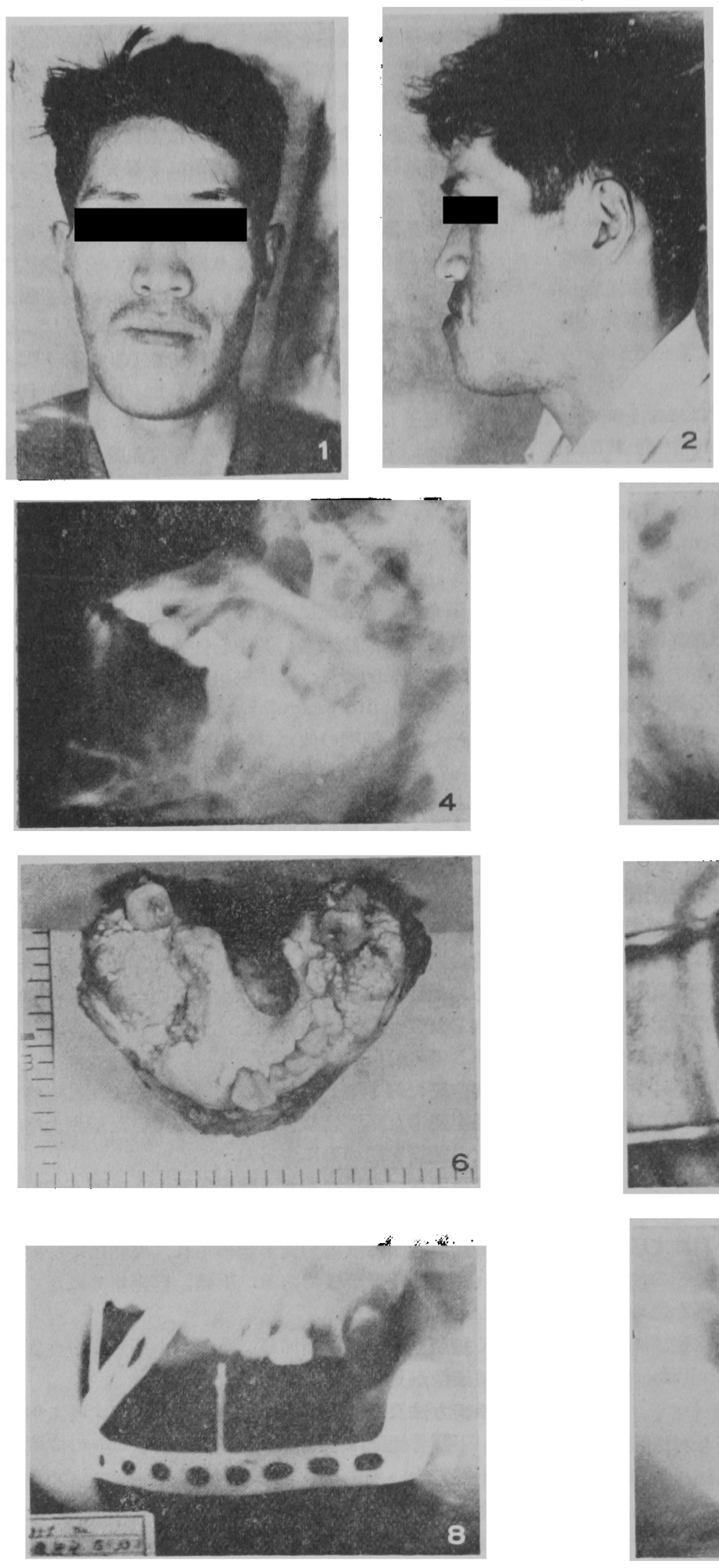
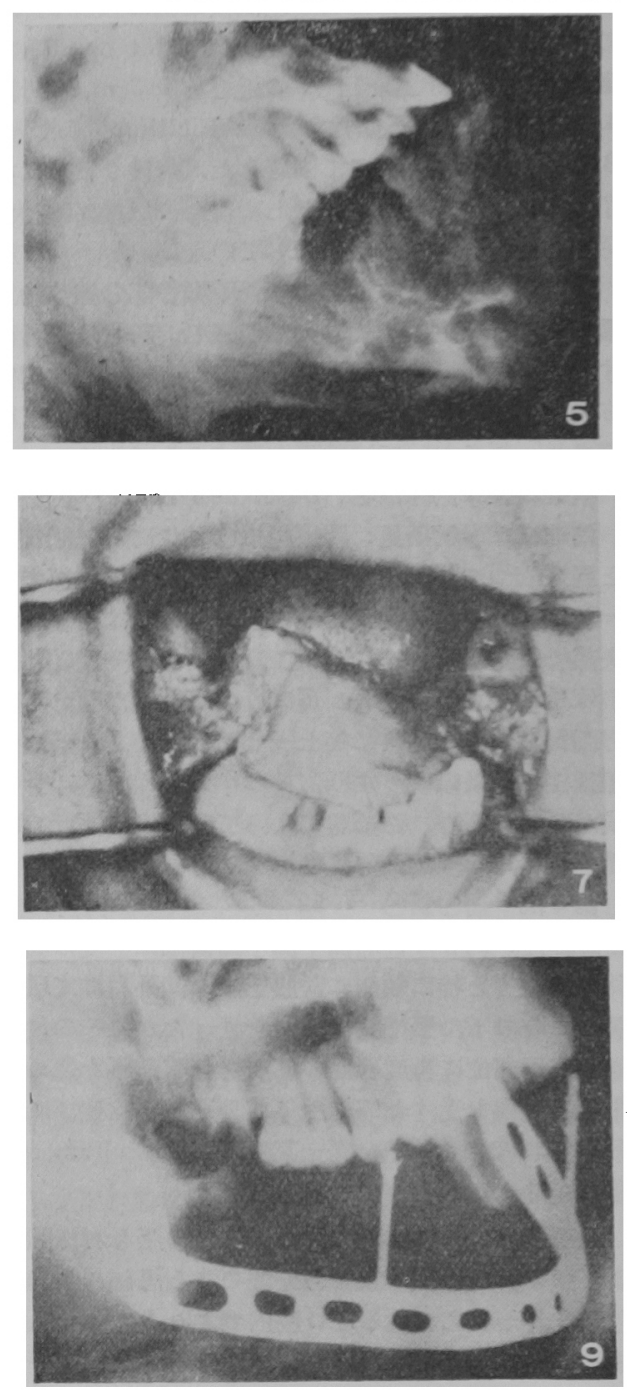


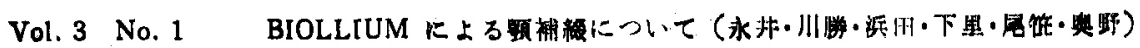
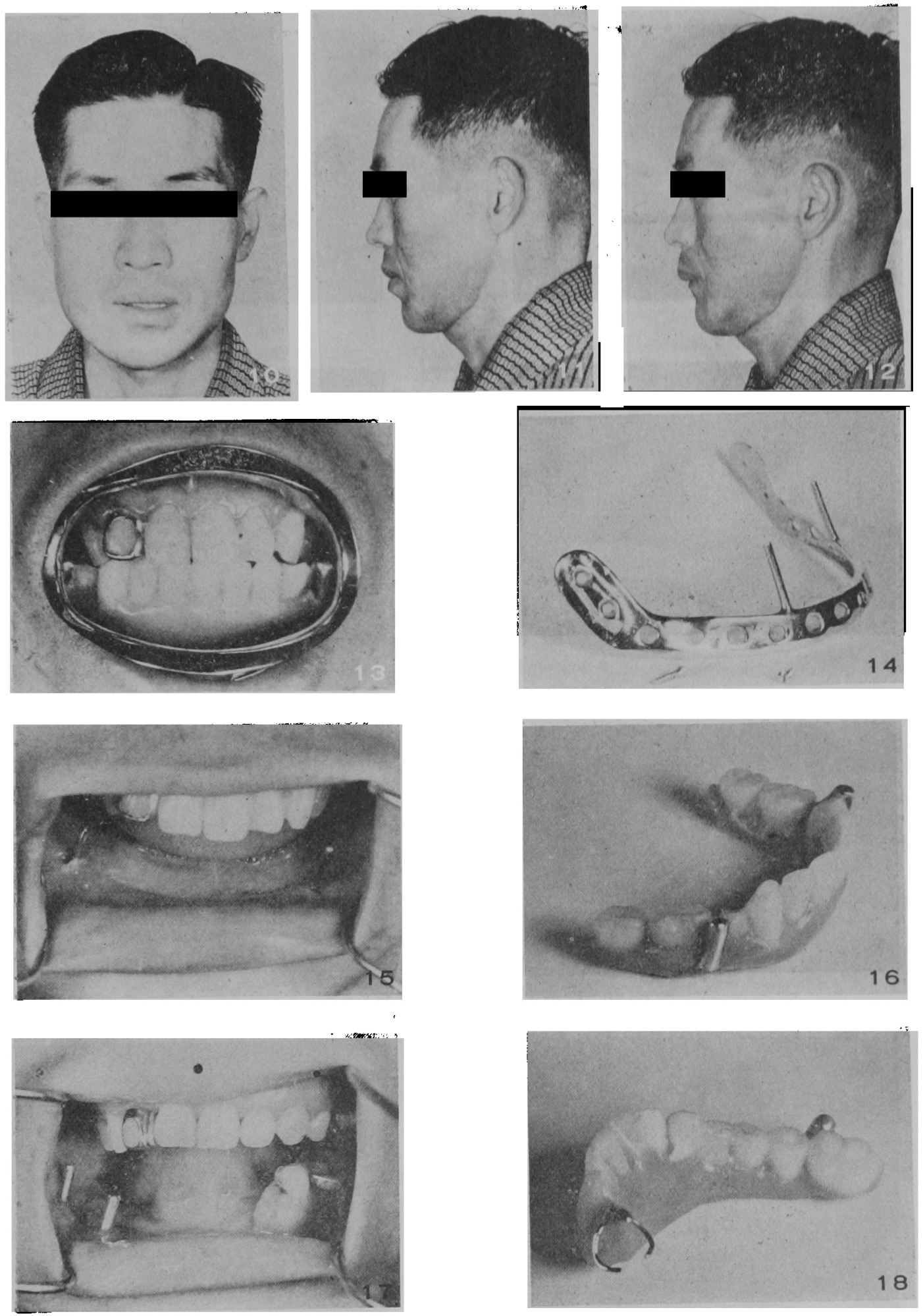

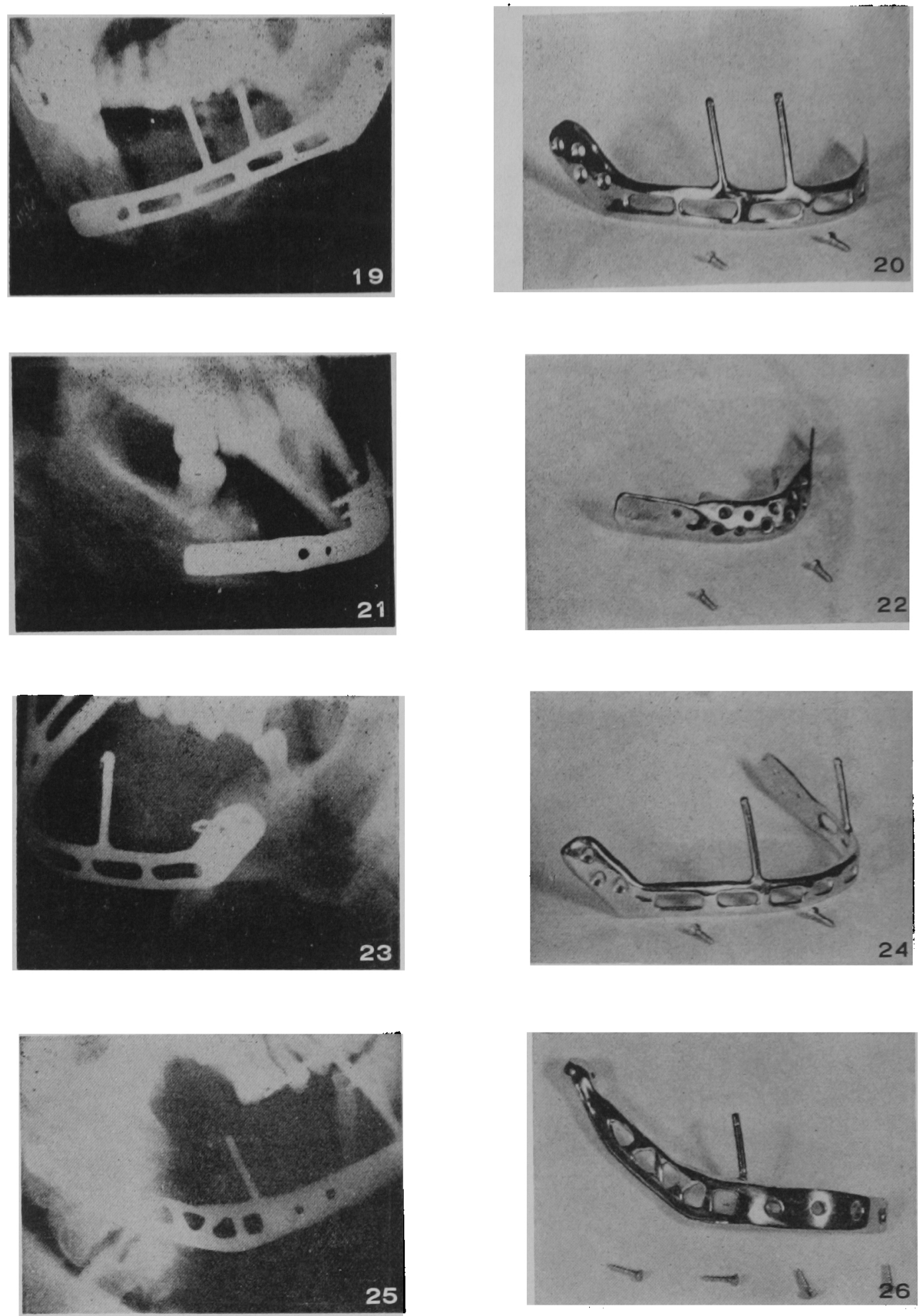


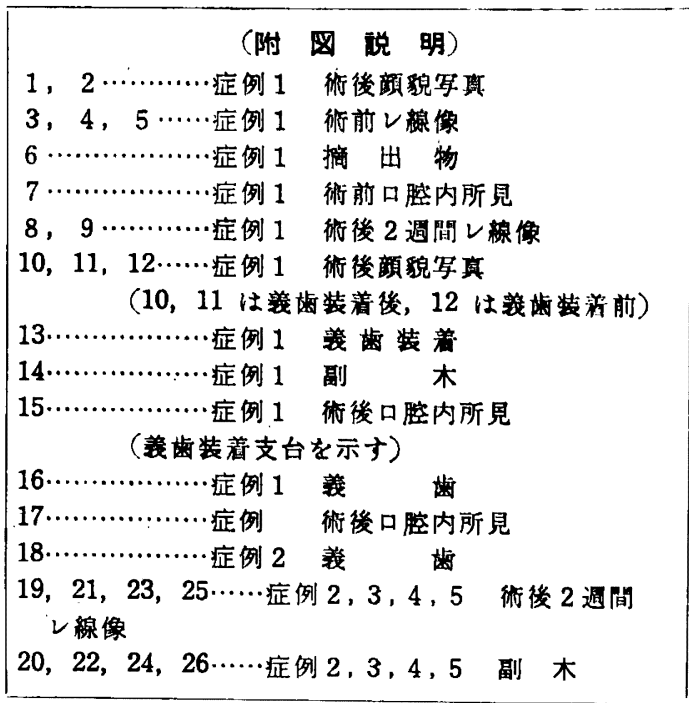

いて Biollium ネジにて固着した，術後 8 日目に抜系完 了. 術後 29 日目に義歯装着, 36 日目に退院せしめ得た.

摘出物: 4 で切断せられた下顎骨右半側関節離断標本 で下顎骨体部より上行枝筋突起にかけて煩舌両側に嘴状 に骨膨隆し，大きさは拳大におよんでいる．制面は帯黄 灰白色で線維様組裁が相交錯すると共にやや膠様の感が ある。

\section{病理組織学的祅断名: Odontogenic mixofibroma}

病理組䍃学的所見：腫瘍実質は線維形成著明な結合織 よりなり太い線維束を形成し所謂 fibroma durum の像 が誢かれるが所々に幼若で myxomatous な部分も認め られる.腫竅実質内には石灰の沈着が見られ，しかもそ れら石灰球の同心円状層状構造を呈し cementicles を 思わせるものがあり更に一部上皮塊が見受けられる.

$$
\text { IV. 考按 }
$$

人体内に金属を封入する央験は 1565 年 Petronéus が 金板を口蓋裂に插入したに始まり，その後 Lapeyode, Liere 等が 1725 年骨折の症例に金属線を使用し，以後 外科手術に銀，アルミニウム等が応用されるよ5になっ たが，これらの金属は体液中の電気作用と，骨およびそ の周团組䅧を刺激乃至破壊し, 又感染防㣦の不完全性等 から充分良好なる結果を得る事が出来なかった．しか し 1929 年 Austernal Laboratories で作った $\mathrm{Cr} 30.8$ $\%, \mathrm{CO} 62.5 \%$, Mo $5.1 \%, \mathrm{Fe} 0.7 \%$, Mn $0.5 \%, \mathrm{Si}$ $0.3 \%, \mathrm{C} 0.4 \%$ の合金である Vitallium は 1936 年 Venable, Stuck, Beach 等が色々の金属の電気伝導度 実験を行いVitallium が体液中で electropassive であ ることを証明し，動物組織に対しても無刺激性で化学変 化を起さない事がわかった。

1949 年 Goldberg と Gershkoff がこの金属を用いて Vitallium Implant Denture に成功したと発表し，そ

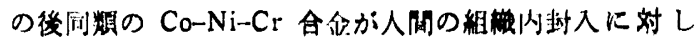

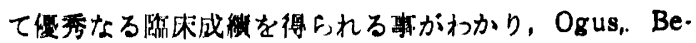
rman，Lew 等によっても研ヶ他用された。闹時に Newman, Van Huysen, Leon Herschfus 等は大をを用い

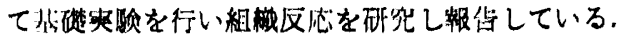

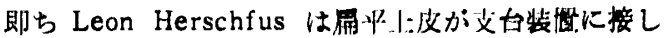

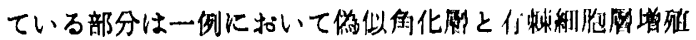

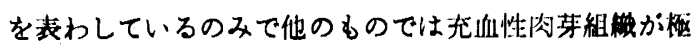

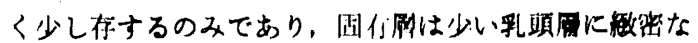

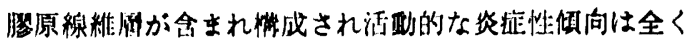
見られず，他う支台装䅦上り连うの部分はりンハ球とフ

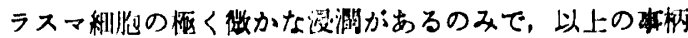
から Vitallium の組归反沁は全くないといってよいと いっている。 しかし口腔内に一部金風が露出しているの で唾液性醏絜や食物残渣や細菌が絶えず接触しその間 烸から浸入する可能性を们しているが彼等の研究では周 りの組䄉が緊密に接着していて一定の盲衰形成や異物の 蓄積については顕徽鏡的に立証し得ないといっていおり， Bodine 中 Kotch その他の臨休的钼察でも侵入路が存 在するように思えないといっている。

しかし Heinrich Hammer は金属露出の部分の周团 には時に異物巨大細胞が出現する事があるといい，慢性 刺激に対して注意を払い支台装䀠の形態および支台装置 頸部の形態に注意を㬇起している.

又 Newman \& Van Huysen は支台の周囲の粘膜は 肥厚し, 丁度人間の歯肉の遊離縁に似ていると述べ,こ れの維持は緊密な結合稀線維の包被によりその位置に保 たれているが骨に固定着床したのによるのではないと述 ベ，この成功不成功は義歯装着支台の周囲の炎症の程度 如何によるものだと結論している．即ち前記三論文は何 れもVitallium の組杫反応の基碟実験であり今回我々 が用いている Biollium ではないがその組成より考えて 殆んど組織反応は変らないのではないかと推論している がこれは今後の研究に待たねばならない，又我々の臨床 経験により優秀なる結果を得ているか，更に長期間の義 海に上る圧迫乃至種々なる慢性刺激に対し如何なる組械 変化を示すかについては更に研究の余地があるのではな いかと考えられる。

\section{V. 結 羭}

1. Biollium 副木を下顎部分切除を要する症例 5 例 に使用し優秀なる臨床経過を得ている。

2. Biollium 副木による下影切除後整復はその副木 の形態と大きさを自由に調整できるので下頷骨の如何な る部分切除にむ用いる事が出来, 且つ外貌の恢復をはか る事が容易である。

3. 5 例中 4 例に義歯装着支台を口腔粘膜上に露出せ しめ義歯を装着し咬合力の恢復を計り，好成績を得てい るが尚長期間の観察を必要とする 2,3 の問題があり， 更に研究の余地があるものと考えられる. 


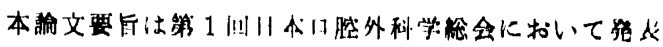
した.

\section{* 苦 文}

1. Leon Rerschfus; Histopathologic Finding" on Vita. llium Implanto in Doge, J of Proth. Dent. Vol. 4, 413 419, 1954.

2. Goldberg, N. I., and Gershkoff, A.: The Lower Implant Denture, D. Digest 88. 490 494 1949.

3. Golderg, N. I., and Gerahkoff, A.: Further Report on the Full Lower Implant Denture, D. Digest, B8, 178 489, 1950.

4. Ogus, W. $L$; Research Report on Implantation of metals, D. Digest. 87, 58 63, 1951.

5. Berman, N.: An Implant Technique for Full Lower Denture, D. Digest 87, 438 443, 1951.

6. Lew, I.: A Simplified Upper Technlque L'ving Immediate Prosthesis, D. Digest 88: 10 15, 1952.

7. Bodine. Jr., R. L. and Kotch. R. L. Experimental Subperiosteal Dental Implants, $U$. S. Armed Rorces Medical Journal, 4: 441 451, 1953.

8. Weinberg, B. D. . Subperiosteal Implantation of a
Vitallium (Cobalt-Chromium Alloy, Artificial Abutment. J. A. D. A. 40: 549 554, 1950.

9. Roy, L. Bodine Jr and Raymond L. Kotch,: Mandibular Subperlonteal Implant Denture Technlque. J. of Proth. Dent, Vol. 4, 396 412, 1954.

10. Pernell. W. E.: Hintory of Implant Work and a Report on Mandibular Implante by the Direct Impreasion Method. J. Proth. Dent. 2: 51 54, 1952.

11. Knowiton. John P. : Masticatory Presaures Excerted with Implant Dentures an Compared with Soft-tienueBorne Dentures, J. Proth, Den. 8: 721 726, 1953.

12. Charles Newman and Grant Van Huyeen: Tineue Reaction to Vitallium Implantation J. Proth. Deat. 4: 850 854. 1954.

13. Heinrich Hammer, Zum Problem der operativen Verbesserung ungunatiger Protheserlager im Unterkiefer bereich, im besonderen durch ubperioeteale Geruat Implantationen Dent. Zahnarzt. ZST $10 \mathrm{~J}$. Nr. 1, 416 146, 1955.

14. Erwin. Reichenbach. : GerUatimplantationen for prothetlache $Z_{w e c}$. Dent. Zahnarzt. Zrt. $10 \mathrm{~J}$. Nr. 1. 447 450, 1955. 